DOI: https://doi.org/10.24144/2409-6857.2019.2(54).79-84

УДК 332.02

Чекан I. В.

\title{
ІНСТИТУЦЙНЕ СЕРЕДОВИЩЕ СТРАТЕГІЧНОГО УПРАВЛІННЯ РЕГІОНАЛЬНИМ РОЗВИТКОМ ЯК СИСТЕМА
}

\begin{abstract}
Розкрита компонентна будова інституційного середовища стратегічного управління регіональним розвитком на засадах системного підходу. Окреслені принципи емерджентної, холізму, складності та структурності, дотримання яких забезпечує функиіонування інституиійного середовища стратегічного управління як системи. Описані функиії системи інституціийного середовища стратегічного управління, до яких віднесено спрямовуючу на досягнення иілій стратегічного управління, інтегруючу в єдину систему всі складові інституційного середовища та комбінаторну, щзо формує різноманітні комбінації інститутів.
\end{abstract}

Ключові слова: регіональний розвиток, конкурентоспроможність, стратегічне управління, інститут, інституційне середовище, системний підхід, принщиипи інституційиого середовища, функції інституційного середовища.

Постановка проблеми. Побудова визначальних конкурентних переваг, що обумовлюють можливості опанування лідерськими позиціями в конкуренції між регіонами, значною мірою залежить від застосування сучасних механізмів адміністрування, серед яких ключову роль відіграє стратегічне управління.

Стратегічне управління регіональним розвитком являється невід'ємною складовою системного, цілісного підходу до формування конкурентоспроможності територіального господарського комплексу. Стратегічне управління визначає цілі, напрямки розвитку та забезпечує менеджмент механізмами для прийняття адекватних управлінських рішень, охоплюючи ландшафт довгострокових перетворень від організаційного поля до сфери людського потенціалу i креативної індустрії. Успішне досягнення стратегічних цілій та застосування важелів довгострокового керування регіональним розвитком значною мірою залежить від інституційного середовища. Останнє виступає умовою ефективного менеджменту, платформою розвитку та одночасно об'єктом управління, що безумовно підвищує його значення в процесі формування стратегічних конкурентних переваг.

Само по собі стратегічне управління представляє собою інститут розвитку, визначаючий широкий спектр правил, втілення яких створює можливості та обумовлює повноваження регіонального довгострокового менеджменту, а також економічних гравців та територіального соціуму. Одночасно умовою

(C) Чекан I.B., аспірантка кафедри економіки i підприємництва ДВНЗ «Ужгородський національний університет», E-mail: irina.chekan@uzhnu.edu.ua якісного довгострокового теріторіального менеджменту $є$ система інститутів, що діє в регіоні й слугує ефективної реалізації стратегічних рішень.

Таким чином, об'єктивною закономірністю в сучасних умовах регіонального життя $\epsilon$ виникнення системи стратегічного інституційного середовища, яке складає базис трансформацій територіальної економіки, спрямованих на побудову стійкої та тривалої конкурентоспроможності.

Як вважає Гречко А.В., «інституціональне середовище, як складна єдність формальних $\mathrm{i}$ неформальних інститутів, грає ключову роль у формуванні позитивного розвитку ... економіки, a іiі якість і міра відповідності інституціональним змінам в країні багато в чому визначаються роллю держави в економіці» [3]. Саме інститути та їх творці формують «правила гри», визначаючи норми поведінки всіх суб'єктів економічної активності.

Значення вказаної проблеми визначено й тим, що інституційне середовище обумовлює вибір шляху інноваційного розвитку регіону або країни 3 двох варіантів: Проактивний або адаптивний. Як доводять словацька дослідниця Юрковічова Л. з ії українськими колегами, «first of all, this is the way of the innovative breakthrough, which provides the development and active use of the basic science and the ability to create radical innovations. The second way is «effective borrowing» or import of innovations, which is not only more economical, but also due to the lag of the innovation process involves a smaller investment of time, which also enhances the effect factor of effectiveness. Not only the countries with low or insufficiently high level economic development choose this way. It has been chosen by Japan, which proved its feasibility»[2]. 
Все це обумовлює доцільність дослідження стратегічного інституційного середовища у взаємозв'язку з іiі системоформуючим бекгроундом.

Аналіз останніх досліджень і публікацій. Проблематика інституційного середовища охопила широкий діапазон поглядів на його сутність, серед яких в першу чергу доцільно виділити політекономічний аспект. Кондратов М.В., Гарипов Р.И. (2015) пропонується «під інституціональним середовищем як економічної категорією розуміти сукупність соціальноекономічних, організаційно-економічних, техніко-економічних і інституційно-економічних відносин 3 приводу формування та реалізації інститутів, метою яких є ефективність розвитку економіки. За цими відносинами стоїть система інститутів, необхідних для досягнення ефективності розвитку економіки» [4]. Сутність інституційного середовища як імпульсу розвитку підкреслена Силиним В.В. (2012), якій вважає, що «інституційне середовище не $є$ простим набором відповідних інститутів, його можна вважати особливого роду інститутом (матрицею розвитку або вектором, що визначає напрям розвитку) вищого порядку. Вона визначає основний напрям розвитку системи, а також ті орієнтири, на основі яких відбувається відбір найбільш ефективних і соціальних інститутів» [10]. Луцьків О.(2014) 3 колегою пропонують на прикладі регіональної структурної політики визначати інституційне середовище як «сукупність формальних (правила, норми, закони та інші юридичні регулятори) та неформальних (уявлення, традиції, звички) інститутів, що регулюють господарськоуправлінську діяльність суб'єктів регіональної політики, а також сукупність цих суб'єктів (інституцій) як інституціолізованих організацій (органи регіонального та державного управління, структури місцевого самоврядування та самоорганізації громадян)»[7]. Петрович Й з його однодумцями (2019) також обмежують сферу інституційного середовища, яке розглядає на прикладі рекреаційної галузі, лише сукупністю формальних та неформальних інститутів, що, на наш погляд, скорочує поле інституційного середовища та масштаб його впливу на стратегічні економічні перетворення [9].

Вказані підходи при всій їх правомірності не розкривають сутність інституційного середовища як складової та фактору стратегічного управління. Крім цього, поза увагою сучасних дослідників залишаться системне бачення інституційного середовища стратегічного управління, що також обмежує дослідження його реального наповнення та можливостей впливу на розвиток регіону

та

його

конкурентоспроможність.

Формулювання цілей статті. Метою даної публікації $\epsilon$ дослідження теоретичних основ інституційного середовища стратегічного управління регіональним розвитком та обгрунтування його композиції 3 позиції системного підходу. Для досягнення мети вирішені завдання: виділені основні компоненти інституційного середовища, комплекс яких діє на засадах системності; представлена характеристика основних системних принципів, що визначають фундамент функціонування інституційного середовища стратегічного управління.

В процесі роботи були застосовані методи індукції та дедукції, наукової абстракції, причино-наслідкового аналізу.

Опис основного матеріалу дослідження. Інституційне середовище стратегічного управління регіональним розвитком являє собою комплексе явище, яке містить сукупність наступних компонентів.

По-перше, вказане середовище являє собою набір інститутів, які діють на певному економічному просторі i визначають правила поведінки учасників соціально-економічної активності на певній території та протягом певного періоду. Крім цього, інституційне середовище стратегічного управління регіональною економікою охоплює ті норми, правила, сфери, в яких приймаються та реалізуються стратегічні рішення. Відмінністю інститутів стратегічного управління від інших інститутів регіонального життя є справність на розвиток, внаслідок якого формуються радикальні, ключові конкретні переваги.

По-друге, інституційне середовище стратегічного управління включає відносини, взаємовідносини між інститутами. Так, в стратегічному управлінні, інститут цілепокладання суттєвим чином обумовлює дію інституту стратегічних рішень, та одночасно знаходиться під його впливом. Наприклад, встановлення цілі значною мірою залежить від правил формування управлінських рішень, застосованих регіональною адміністрацією (наприклад, правила та методи оцінки ризиків, правила формування команди управлінців і т.п.).

По-трете, інституційне середовище стратегічного управління включає його безпосередніх учасників, 3 набором їх якостей, власного бачення розвитку, стратегії і т.д. Так, орієнтація стратегічного управління на інноваційний розвиток передбачає не лише правила гри на полі інноваційної активності, але 
й вимоги до самих гравців, здатних функціонувати 3 інноваційною спрямованістю та маючих перед собою в якості мети побудову інноваційних конкурентних переваг. Іншими словами, інститути є правила, але виконуватися вони можуть лише при наявності економічних або соціальних гравців, здатних та бажаючих жити та діяти за встановленими в середовищами правилами.

По-четверте, внаслідок великого значення культури регіонального суспільства наступною складовою виділяємо культуру регіону, при тому що іiї можливо віднести до окремого інституту. Значення культури, яке дозволяє виділять в окрему частину інституційного середовища, підкреслено Кубіній Н.Ю. та іï однодумцями через функції культури у складі тріади з туризмом та економікою в системі стратегічного регіонального розвиту. Так, автори доводять, що «first function brings the adaptation of regional economic systems to the modern economy, knowledge economy, which is based on people, information and culture. Second supports the human development of both individuals and within the region, as well as at higher levels of public life. Third one forms a multicultural regional environment, the foundations of which are tolerance, respect and trust, which in turn are the conditions for productive economic activity»[1] Ми розглядаємо культуру як платформу, базис не лише для прийняття стратегічних рішень та іï реалізації, але й для ефективної взаємодії між іншими інститутами. Так, наприклад, культура, побудована на довірі до державної чи регіональної влади, сприяє ефективному функціонуванню інститутів податків, про що свідчить досвід Норвегії, Фінляндії та інших соціально й економічно розвинених територій.

I, на кінець, вважаємо за доцільне включити в стратегічне інституційне середовище тактику, від якості, ефективності та доцільності якої залежить імплементація стратегічних рішень. Крім цього, неможливо не відмітити, що стратегічне управління, його результативність залежить від тактики, обраної регіональною адміністрацією, а оперативні дії завжди лежать в інституційному поточному полі. Під тактикою в даному дослідженні ми рекомендуємо розуміти сукупність правил, які лежать в основі практичного здійснення стратегічно орієнтованих акцій. Тактика є площадкою, на якої зустрічається реальне регіональне життя, його можливості, ресурси, бачення, правила існування з вказаними стратегічними цілями. Якщо стратегія у військових розглядається як «план генерала», то тактика вже являє собою «мистецтво бою».
Відповідно, в стратегічному управлінні тактика $€$ мистецтвом вести поточне життя за правилами та орієнтирами, заданими стратегією розвитку регіональної економіки. Підтвердженням значення інституту тактики як складової стратегічного інституційного середовища звучать висновки, що випливають 3 дослідження перемоги А. Македонскького, якій для досягнення стратегічних цілій впроваджував в оперативному плані «технико-технологические инновации..., обеспечивающие скорость достижения оперативных целей при экономии ресурсов, в том числе и человеческих. 2. Политические новации, которые формируют благоприятную внешнюю среду для осуществления поставленных задач. 3. Организационно-управленческие инновации, которые мотивируют участников действий. 4. Экономические инновации, предполагающие нетрадиционные экономические решения»[6].

Таким чином, інституційне середовище стратегічного управління представляє собою системне утворення, що включає інститути розвитку та взаємодію між ними; учасників стратегічних дій - акторів середовища; культуру як базис, на якому розташоване середовище; тактику як площину та сферу діяльності, що забезпечує реалізацію стратегічних цілій. Іншими словами, доцільно розглядати інституційне середовище з позиції системного підходу, якій передбачає « напрям методології дослідження, в основі якого лежить розгляд об'єкта як цілісної безлічі елементів у сукупності відносин і зв'язків між ними, тобто розгляд об'єкта як системи» [5].

Система інституційного середовища стратегічного управління (СICCУ) функціонує за принципами, які включають:

1. Принцип емерджентності, якій забезпечує цілісність системи на основи опанування нею якостей, відсутніх у елементів системи. Так, ціль СІССУ відрізняється від мети дії певних інститутів. Крім цього, система інституційного середовища стратегічного управління регіоном характеризується певною збалансованістю інститутів, взаємовідносин та учасників, що відбувається протягом певного періоду часу i завершуєтеся появою точки біфуркації.

2. Принцип холізму, якій також відповідає за цілісність СІССУ, але передбачає первинність, більшу значимість цілого у порівнянні з його частинами. Принцип холізму відіграє особливу роль у стратегічному управлінні, поставив во главу кута цілі регіонального розвитку як пріоритетні над завданнями окремих його учасників . 
3. Принцип складності, що дозволяє розглядати систему інституційного середовища як явище 3 великим набором складових, взаємодія та взаємовплив яких можуть обумовити багатоваріантність ії функціонування та розвитку. Так, стратегічна мета регіонального економічного розвитку обумовлена як стратегічним потенціалом акторів економічних дій, так й регіональною культурою, що сприяє або гальмує реалізацію їх потенційних можливостей.

Стратегічне інституційне середовище за своєю природою відноситься до відкритих систем, на дію яких значний вплив оказує зовнішне оточення, якій в сукупності з впливом внутрішніх складових викликає іii, системи, флуктуацію, тобто коливання, відхилення від середнього значення або позиції ¥ї функціонування. Флуктуація, як доводить теорія систем, виступає джерелом біфуркації.

Біфуркація системи стратегічного інституціонального середовища являе собою точку, що виникає внаслідок впливу зовнішніх та внутрішніх факторів й елементів, проходження якої надає системі декілька варіантів майбутнього шляху функціонування та розвитку.
Ляховець О. поділяє середовище на сприятливе для розвитку та несприятливе, До несприятливих, наприклад, вказаний автор відносить «розвиток автократичних інститутів, закріплення владних повноважень за невеликою групою осіб», а до сприятливих - серед інших «орієнтованість на суспільний добробут; чітка специфікація та захист прав власності, повага до закону, низький рівень опортунізму при виконанні контрактів; розвиненість соціального страхування»[8].

Функції інституційного середовища стратегічного управління регіональним розвиток включають наступні: спрямовуюча ( визначає найбільш ефективні шляхи розвитку регіональної економіки, які враховує система стратегічного менеджменту). Інтегруюча (об'єднує суб'єктів та об'єктів стратегічного управління регіональним розвитком, а також забезпечує органічність входження системи управління в систему розвитку регіону. Комбінаторна - поєднання інститутів шляхом створення оптимальної інституційної системи, яка забезпечує ефективне та раціональне функціонування середовища.

Таким чином, СІССУ представлена на рис.1.

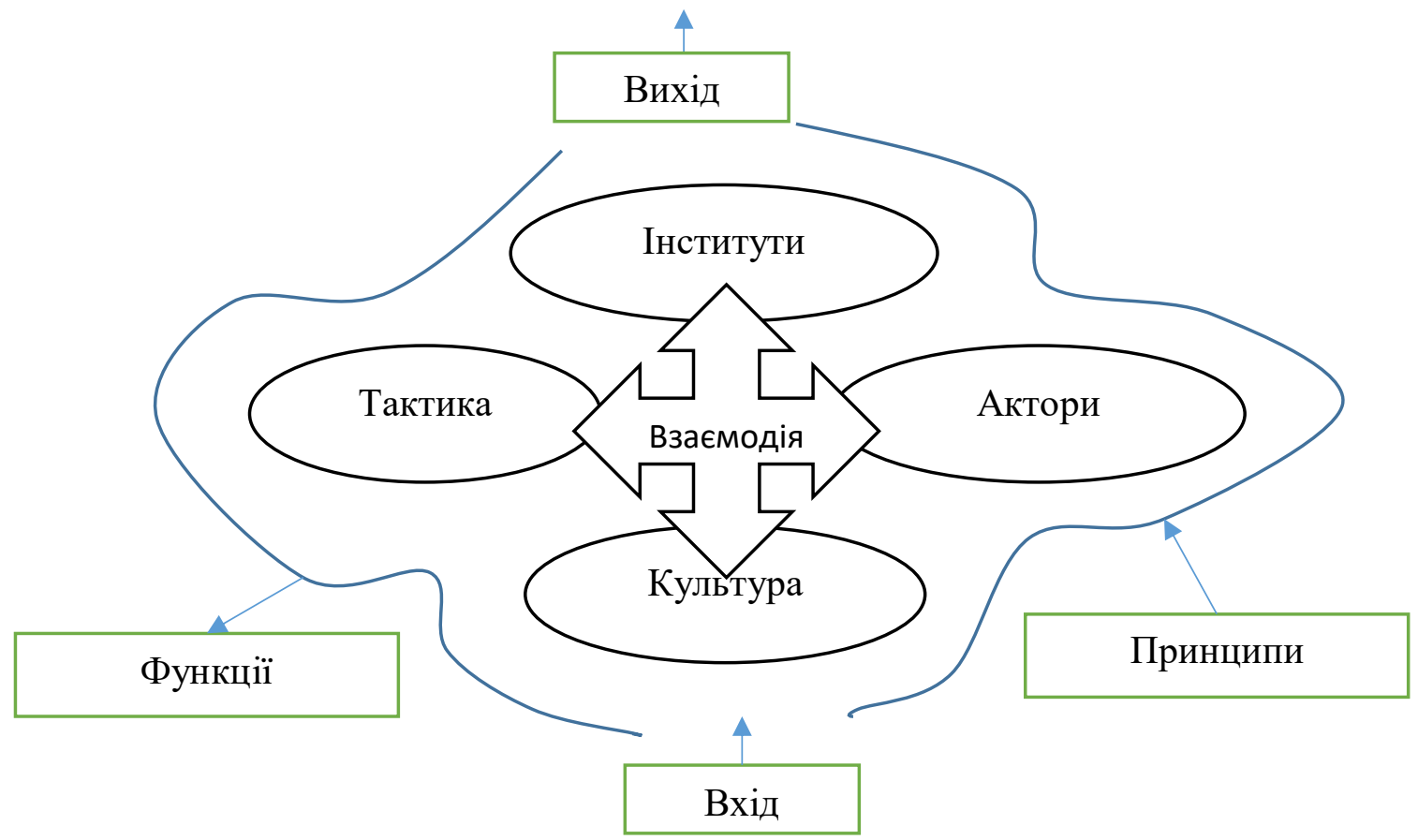

\section{Рис. 1. Система інституційного стратегічного середовища стратегічного управління * *складено автором}

Системний підхід забезпечує широту аналізу існуючого інституційного середовища та окреслює перспективу його застосування в системі стратегічного управління для досягнення регіональних конкурентних переваг.

Висновки i перспективи подальших досліджень. Інституційне середовище страте- гічного управління, виконуючи функції фундаменту ефективних довгострокових управлінських рішень, $є$ безумовно визначальним фактором побудови радикальних, ключових конкурентних переваг регіональної економіки. 3 позиції системного підходу запропоновано інституційне середовище стратегічного 
управління визначати як системне утворення, що включає інститути розвитку та взаємодію між ними; учасників стратегічних дій - акторів середовища; культуру як базис, на якому розташоване середовище; тактику як площину та сферу діяльності, що забезпечує реалізацію стратегічних цілій.

Інституційне середовище набуває системного характеру за умови дотримання принципів: емерджентності, якій забезпечує цілісність системи на основи опанування нею якостей, відсутніх у елементів системи; холізму, якій також відповідає за цілісність системи інституційного середовища, але передбачає пріоритетність цілого у порівнянні 3 його частинами; складності, що дозволяє розглядати систему інституційного середовища як явище 3 великим набором складових.

Основними функціями інституційного середовища стратегічного управління виділені таки як спрямовуюча, інтегруюча та комбінаторна.

В подальшому заплановано дослідження взаємодії інституційного середовища стратегічного управляння та регіональної культури як умови прийняття адекватних рішень та ефективної їх реалізації.

\section{ПЕРЕЛІК ВИКОРИСТАНИХ ДЖЕРЕЛ}

1. Kubiniy N., Culture, tourizm and economy as a triumvirate of regional strategic development / Kubiniy N., Belen M., Zavadyak R.// Науковий вісник Херсонського державного університету. Серія «Економічні науки» - 2019 - Випуск 34 - с. 100-103.

2. Kubiniy $\mathrm{V}$. The formation of the national innovation system as a basis for strengthening the innovation potential of the country/ Volodymyr Kubiniy - Galyna Kish - Lujza Jurkovičová // Journal of Environmental Protection, Safety, Education and Management - 2016 - No8 - Vo4 - p.11-16

3. Гречко А.В. Роль інституційного середовища у розвитку національної економіки. / Гречко А.В.// Сучасні проблеми економіки і підприємництво. - 2013. -№11. Режим доступу: http://sbkeip.kpi.ua/article/view/47802

4. Кондратов М.В. Институциональная среда как экономическая категория / Кондратов М.В., Гарипов Р.И. // Вестник СМУС - 2015 - №1 (8). - c.40-43

5. Конкурентоспроможність економічних систем та стратегічне управління нею: гносеологічний та утилітарний ракурси: монографія / В.П. Мікловда, Ф.Ф. Шандор, Н.Ю. Кубіній, С.М. Мошак, Ю.О. Дідович, В.О. Огородник, Я.С. Максимчук, В.В. Кубіній; Ужгород: Карпатська вежа, 2015. - 420 с.

6. Кубиний Н.Ю. Институализация инновационніх стратегий: ретроспектиивній бекграунд [Текст] / Н. Ю. Кубиний, Е. В. Пулянович, Т. И. Косовилка // Науковий вісник Ужгородського університету : Серія: Економіка- Ужгород : Говерла, 2017. - Вип. 2 (50). - С. 83-86.

7. Луцків О.М. Інституційне середовище регіональної структурної політики / О. М. Луцків, М. В. Максимчук // Регіональна економіка. - 2014. - №3. - ,с.37-47.

8. Ляховець О.О. Формування інституційного середовища в процесі модернізації економіки. / О.Ляховець // Економіка і регіон . - №4 (47) - 2014 - ПолтНТУ. - с.113-119.

9. Петрович Й. Інституційне середовище як важлиавоа передумова розвитку туристичнорекреаційної сфери/ Петрович Й., Бондаренко Ю., Просович О.// Проблеми економіки та управління. 2019 - Вип. 6. - Номер 3. - с.3-15.

10. Силин В.В. Институциональная экономика [текст] / В.В. Силин, Н.М. Улицкая; М.: Московская академия рынка труда и информационных технологий - 2012. -82 с.

\section{REFERENCES}

1. Kubiniy N., Belen M., Zavadyak R. (2019). Culture, tourizm and economy as a triumvirate of regional strategic development. Naukovyi visnyk Khersonskoho derzhavnoho universytetu. Seriia «Ekonomichni nauky» - Scientific Bulletin of Kherson State University. Economic Sciences Series, 34, 100-103 [in English].

2. Kubiniy V. Kish G., Jurkovicova L.(2016). The formation of the national innovation system as a basis for strengthening the innovation potential of the country. Journal of Environmental Protection, Safety, Education and Management, 8, Vo4,11-16 [in English].

3. Grechko A. (2013). Rol instytutsiinoho seredovyshcha u rozvytku natsionalnoi ekonomiky. [The role of the institutional environment in the development of the national economy] Suchasni problemy ekonomiky $i$ pidpryiemnytstvo - Modern problems of economy and entrepreneurship, 11. Retrieved from: http://sbkeip.kpi.ua/article/view/47802 [in Ukranian]. 
4. Kondratov M.V., Harypov R.Y. (2015). Ynstytutsyonalnaia sreda kak эkonomycheskaia katehoryia [Institutional environment as an economic category]. Vestnyk SMUS - Bulletin of SMUS, №1 (8), 40-43 [in Russian].

5. Miklovda V. Shandor F., Kubiniy N., Moshak S.,. Didovych, Ohorodnyk V. et al. (2015). Konkurentospromozhnist ekonomichnykh system ta stratehichne upravlinnia neiu: hnoseolohichnyi ta utylitarnyi rakursy: monohrafiia [Economic systems competitiveness and strategic management: epistemological and utilitarian perspectives]. Uzhhorod: Karpatska vezha [in Ukrainian]

6. Kubiniy N., Puljanovich E.,Kosovilka T. (2017). Ynstytualyzatsyia ynnovatsyonnikh stratehyi: retrospektyyvnii bekhraund [Institutionalization of innovative strategies: retrospective background]. Naukovyi visnyk Uzhhorodskoho universytetu - Uzhgorod University Scientific Bulletin, 2(50), 83-86 [in Russian].

7. . Lutskiv O. M., Maksymchuk M. V. (2014). Instytutsiine seredovyshche rehionalnoi strukturnoi polityky [The institutional environment of regional structural policy]. Rehionalna ekonomika- Regional economy, 3, 37-47 [in Ukrainian].

8. Liakhovets O.O. (2014). Formuvannia instytutsiinoho seredovyshcha v protsesi modernizatsii ekonomiky [Formation of institutional environment in the process of economic modernization]. Ekonomika $i$ rehion - Economy and region, 4, 113-119 [in Ukrainian].

9. Petrovych Y., Bondarenko Yu., Prosovych O. (2019). Instytutsiine seredovyshche yak vazhlyavoa peredumova rozvytku turystychno-rekreatsiinoi sfery [Institutional environment as an important prerequisite for the development of tourism and recreational sphere]. Problemy ekonomiky ta upravlinnia. Problems of economy and management, 6, 3, 3-15 [in Ukrainian].

10. Sylyn V.V., Ulytskaia N.M. (2012). Ynstytutsyonalnaia эkonomyka [Institutional economy]. Moskovskaia akademiya rynka truda i informatsyonnykh tekhnologii [in Russian].

Отримано 01.09.2019 